\title{
The US Presidential Election of 2016 and the Political Socialization of
}

\section{8th-Graders}

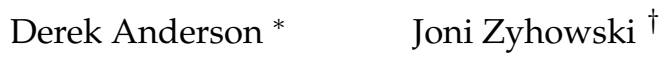

\begin{abstract}
This mixed-methods study examined the political typologies, perspectives, and presidential preferences of 115 8th-grade students both six weeks before and on Election Day 2016. Data from the Pew Research Center's Political Typology quiz, surveys, coursework, and classroom observations revealed the students political candidate preferences were stable, though their political ideologies were quite malleable, with more than half (55\%) of the students' political typologies changing over the six weeks. After the election, most students expressed disdain and fear, yet few were able to express actions they could take to engage in the political process.
\end{abstract}

Keywords: Political socialization; Trump; Clinton; election.

\section{Introduction}

Political participation among the young has always been low (Tingsten, 1937). The younger a person is, the less likely she is to be interested in or knowledgeable about politics Dalton (2009), yet the more exposure children have to politics, the more interested they become (Cohen \& Kahne, 2011). Additionally, the more interested students become in politics, the more likely they are to be politically active (Levy, Solomon, \& Collet-Gildard, 2016). While the political interest of adults is largely established (Prior, 2010), adolescents' political interest is malleable (Levy, Journell, He, \& Towns, 2015; Neundorf, Smets, \& García-Albacete, 2013). Adolescents' political interest certainly is influenced by parents Neundorf et al. (2013), but classroom activities including discussions (Kahne, Crow, \& Lee, 2013; Levy et al., 2016) can also enhance adolescents' political interest and activities.

Classrooms can serve as "schools of democracy" (van Ingen \& van der Meer, 2016) where students interact with differing viewpoints, practice their civic skills, and have their curiosity about politics piqued. Combined with parental and community influences, schools can boost students' civic interest and engagement (Youniss et al., 2002), despite reports suggesting today's youth view government and politics with distrust, disengagement, and apathy (Gordon \& Taft, 2011). Although youth tend to be disinterested in politics, exigent events, such as wars and scandals, can heighten students' interest in politics and "leave an indelible impression" (Niemi \& Hepburn, 1995). Political events play a

\footnotetext{
*School of Education, Northern Michigan University, Marquette, MI, United States

Email: dereande@nmu.edu

${ }^{\dagger}$ School of Education, Northern Michigan University, Marquette, MI, United States
} 
critical role in the political socialization process of students, and seminal political events, such as the Vietnam War, the fall of the Berlin Wall, and perhaps the Presidential Election of 2016 can accelerate the political socialization process (Sears \& Valentino, 1997).

\section{Purpose of this Study}

Despite decades of research on the political socialization of youth, much of that research is old and has investigated data from panel studies. A scarcity of research has examined the development of and change in students' political preferences, and none has studied students in the classroom during a unit of instruction. Despite warnings that researchers should "be cautious about studying most political topics with children under fourteen" because "many political concepts are either overly complicated or not in their realm of interest" (Niemi \& Hepburn, 1995), we chose to examine 8th-grade students' perspectives on the candidates and issues leading up to and following the Presidential Election of 2016. Our specific research questions were:

1. Prior to studying the 2016 Presidential Election in their social studies classes, what did 8th-grade students from a rural middle school in the Upper Midwest report to be their source of election information and preferred candidates?

2. What were the political typologies of the students prior to studying the election, and how did their typologies relate to their preferred candidates?

3. How did the students navigate the election unit?

4. What were the political typologies of the students after studying the election for six weeks in their social studies classes, and how did their typologies relate to their preferred candidates?

5. How did the students process and reflect on the election following the results?

\section{Political Socialization}

Political socialization is a complex process and difficult to define. In general, political socialization is a process by which individuals learn social patterns and agencies, as well as their political attitudes and behaviors (Hyman, 1959). Most definitions of political socialization reference "the transmission of political culture to new generations of citizens" (Owen, 2008). Political culture consists of people's values, beliefs, opinions, attitudes, and actions. Questions over "how and when individual political orientations are shaped" have occupied political socialization researchers since the 1950s (van Deth, Abendschon, \& Vollmar, 2011).

Rooted in social learning theory (Jennings \& Niemi, 1968), political socialization can be examined on a micro and macro level (Sapiro, 2004). On a micro level, political socialization frames how individuals develop their political understanding and contextualize 
their lives. The micro-level approach to political socialization draws from the field of socialization generally, and childhood socialization specifically (P. J. Conover, 1991). On a macro level, political socialization frames how groups and systems transmit practices and norms to its members (Sapiro, 2004). The macro-level approach to political socialization draws from the field of systems theory (Easton, 1965).

\section{Political Socialization and Youth}

In the 1960s, researchers learned that children as young as six years old could articulate feelings about political parties (Niemi \& Hepburn, 1995). During the 1960s and 70s, family context, and in particular - parental behavior, were thought to be the primary determinants of political socialization (Dawson \& Prewitt, 1977; Greenstein, 1965; Weissberg, 1974).

Hess and Torney (1967) identified four political socialization models for youth. The Accumulation Model suggests that children learn from lessons, and despite their age, they can learn a great deal and are only limited by their exposure. The Interpersonal Transfer Model suggests that children's political socialization comes from their family. Similarly, the Identification Model identifies parents as having the primary impact on children's political socialization; however, the parental modeling is without intent. Finally, the Cognitive Development Model suggests that children are limited in their political thinking by their cognitive stages.

Political socialization is a foundational component of adolescents' self-categorization. Self-categorization theory explains that a person's personal beliefs and attitudes are embedded in a social context (Tajfel, Billig, Bundy, \& Flament, 1971; Turner \& Reynolds, 2011). This combination of one's personal attributes with influence of group membership helps to explain why political party identification is stable (Goren, 2005). As children move through the early adolescence of middle school into high school, they solidify their personal and social identities (Mizelle \& Irvin, 2000). Their personal identities stem from their determinations of what they believe in, who they want to become, and how they want others to see them (Nelms, Allen, Craig, \& Riggs, 2017; Ritchie et al., 2013). Their social identities relate to the groups they want to be part of and correspondingly how members of that group act (Hogg \& Terry, 2000). Adolescence is the prime time for identity formation (Youniss et al., 2002; Youniss, McLellan, \& Yates, 1997). It is during adolescence that individuals' self-categorizations related to their political ideologies begin to crystallize (Flanagan, 2009).

\section{Political Socialization and Schools}

The role of schools in influencing students' attitudes and leanings began to gain attention with Hess and Torney (1967)'s seminal study of 17,000 schoolchildren, from which they concluded, "the school stands out as the central, salient, and dominant force in the political socialization of the young child". They acknowledged that family is important in the political socialization of children, but is often overrated. Massialas et al. (1970) suggested that schools impact the political system in four ways, including: political socialization of 
students, training of political leaders, politically integrating communities, and fostering of special interest groups. Arguably, schools cannot not teach political knowledge and skills. By their very nature, schools teach rights, duties, rules, codes, ethics, and the organization of human capital for a common purpose, which are all preparation for citizenship (P. Conover \& Searing, 2000).

Schools can play a direct role in increasing students' social trust. When schools foster a sense of belonging and group identity, students tend to believe their fellow citizens are trustworthy and well-intended, which improves civic-mindedness and commitment to democracy (Flanagan \& Levine, 2010; Uslaner, 2017). Flanagan, Stoppa, Syvertsen, and Stout (2010) warned that standard instruction alone is not enough to advance the political socialization of students. Students also need opportunities to work together, to voice their views, and to hear those of fellow students. Schools provide essential opportunities for diverse political discussions because in many cases students will face a much more diverse population of people and opinions than they will outside the school walls.

How social studies teachers should teach, in general, is an enduring question. More specific are questions related to how social studies teachers should teach to develop students' civic and political skills and dispositions. Because teachers hold authority over students, they play a critical role in educating children about democratic principles (Flanagan \& Levine, 2010). Students who possess higher knowledge of the Constitution and students who are taught in engaging, student-centered classrooms are more likely to be politically engaged. Traditional, lecture-based approaches to social studies teaching are less effective at fostering political engagement (Owen \& Soule, 2015). The deliberate teaching of controversial issues provides students with opportunities to work on public problems and debate social issues (McLeod, Shah, Hess, \& Lee, 2010). When teachers teach students about the political process, discuss controversial issues, and provide students with service learning opportunities, students' political and civic engagement increases (Kahne et al., 2013). However, how and when the transmission of civic and political engagement are transmitted is not clear and needs further study (Owen, 2008).

\section{Methods}

We used a partially mixed, sequential mixed-methods design (Leech \& Onwuegbuzie, 2009), combining quantitative data from the students' presidential candidate preferences and political typologies with qualitative data from their questionnaire responses and coursework. This complementarity provided clarification and enhancement of the political socialization phenomenon, as well as for convergence and corroboration (Onwuegbuzie \& Leech, 2004).

\section{Participants}

The 8th-grade students were 91\% White, 6\% Multiracial, 2\% Hispanic, .5\% African American, and .5\% Asian. Far below the national average of $50 \%+$ of students who qualify for free or reduced lunch prices (Snyder \& Musu-Gillette, 2015), 21.6\% of the students in this 
study qualified for free lunch and 5.2\% qualified for reduced lunch. During April of the previous school year, the students took standardized state tests in three subjects, math, science, and English-language arts, on which they scored higher than the state average on all three. In short, the students in this study were predominantly White, middle-and upper-middle-class, and high-achieving. The entire class consisted of 212 8th-grade students, though 115 students completed all components of the study.

The two social studies teachers - one, a White female in her early 40's and the other a White male in his late 20's - each had four sections of Social Studies 8 with randomly assigned students.

We met with the two teachers two times - once for 30 minutes, and once for $70 \mathrm{~min}$ to discuss their plans for teaching the presidential election and to share our ideas for the study. Together we drafted the questions we would ask students and settled on the PEW Typology quiz. The lesson planning for the unit was almost entirely done by the teachers, but we asked probing questions and provided some input and materials.

Starting the week of September 27, 2016, the teachers began a six-week unit leading up to Election Day. Because their curriculum included primarily United States history from the Revolution through Reconstruction, the teachers sought to integrate their study of the election with a unit titled, Challenges to an Emerging Nation, which included such topics as political conflict, regional economic growth, and the rise of reform movements. Furthermore, the teachers planned to address some of their state curriculum standards related to public discourse, decision-making, and citizen involvement.

Throughout the unit, the two teachers integrated lessons on the presidential election into their US History course. Week One focused on social issues. In Week Two, students studied political party affiliation, past and present. During Week Three, students researched the platforms and actions of the presidential candidates. Week Four focused on political ads and propaganda. During Week Five, students made political ads for the candidate of their choice and wrote letters to the presidential candidates. Finally, Week Six focused on the Electoral College and voting rights. The election was held on Tuesday of the seventh week.

\section{Data Collection}

The teachers authorized an open-door policy regarding their lessons and an open-book policy regarding their materials. We could drop in at will, which we did four times with warning, and four times without, to conduct observations. They shared their lesson plans and assessments, as well as examples of student work. Additionally, we engaged in frequent conversations with the teachers - almost daily - via email, text, or face-to-face.

Non-instructional data consisted of a short questionnaire and a typology quiz that the students took twice - once at the start of the six-week unit, and again on Election Day. At the start of the unit, the students answered the following questions:

1. On a scale from 0 to 10 ( 0 being not at all, and 10 being very much), how much do you know about the upcoming presidential election? 
2. From where do you get your information about the presidential election? Please be specific.

3. If the election were held today, whom would you vote for and why? Please explain.

Next, they took the Pew Research Center's Political Typology quiz, which stems from a 1988 study, The People, the Press, and Politics, conducted by Times Mirror (Ornstein, Kohut, \& McCarthy, 1988). The Pew Political Typology classifies people into one of eight groups "based on their attitudes and values, not their partisan labels" (Dimock, Doherty, Kiley, \& Krishnamurthy, 2014). Two of the eight groups, Steadfast Conservatives (critical of the government and the social safety net) and Business Conservatives (prefer limited government, and support Wall Street, business, and immigration reform), align with today's Republican party platform, and one group, Steadfast Liberals (support liberal ideals comprehensively), align with today's Democrat party. On the other hand, five of the eight groups are neither strongly liberal or conservative; rather, this middle ground is multifaceted with Americans holding a mix of attitudes and values, "often with as little in common with each other as with those who are on the left and the right" (Dimock et al., 2014). These five typologies include: Young Outsiders (dislike both political parties), Hard-Pressed Skeptics (resent government and business but support welfare programs), Next Generation Left (liberal on social issues, but economically moderate), Faith and Family Left (lean left but socially conservative), and Bystanders (pay little attention to politics and do not vote).

Throughout the six weeks, students participated in variety of lessons focused on the election process generally and the candidates specifically. Students watched speeches, analyzed and created political ads, debated agenda, and wrote letters and essays.

On Election Day, the students voted in a school-wide mock election anonymously. Thus, we cannot be certain of which candidate each student actually voted for. However, at the end of Week Six, students were required to campaign for a candidate. The teachers reported they did not think any students mockingly campaigned for a candidate they did not support. Therefore, we recorded the candidate each student campaigned for, assuming that was the candidate they voted for.

The day after the election, the teachers created an unplanned assignment to help students articulate their thoughts and feelings about the election. The quadrant template asked students to express their fears, hopes, questions, and ideas for what they could do now that the election was over.

\section{Data Analysis}

We used frequency tables to organize the data from the students' Pew Political Typology quizzes and candidate preferences. We used constant comparison analysis (Strauss \& Corbin, 1998) to analyze the qualitative data from the students' responses to the questionnaire, as well as their class assignments. Through open coding, we organized the data into small in vivo units - either single words or short phrases. Next, we grouped these units into categories, saturating the data. Finally, generating themes where possible to express the essence of each group. Throughout the process, we coded cooperatively, deliberating 
and reconciling any discrepancies together (Campbell, Quincy, Osserman, \& Pedersen, 2013).

\section{Findings}

\section{Pre-Election Candidate Preferences}

Six weeks before the election, $41 \%$ of the students declared they would vote for Hilary Clinton if the election were held that day, $27 \%$ stated they would vote for Donald Trump, and $31 \%$ for none of the candidates.

When asked to list where they got their information about the candidates, $82 \%$ of students said TV, which was more than twice the second-most common response of family $(40 \%)$. Only $17 \%$ of students said they got information from social media, an equal number to those who stated, friends.

When asked to explain why they were supporting their preferred candidate, the students provided a wide array of responses, from which several themes emerged. Most commonly, students expressed disdain for the other candidate in their reasoning for supporting their preferred candidate. Students sometimes wrote dogmatically that they were supporting Clinton because, "She's not Donald Trump," or that they were voting for Trump because, "Anyone is better than Hillary." Nearly 1/3 of the students noted that they were not supporting either candidate. Of these, most acknowledged that they lacked information. For example, one student wrote, "I don't know because I don't have enough information to decide." Others made comments like, "I would not vote because I do not like any of them."

Commonly, students provided specific reasons why they opposed the other candidate, including their policies and their character. Clinton supporters expressed disagreement with Trump's plans to build a wall on the US-Mexico border. For example, one student wrote, "Hillery (sic) because she's not spending Americas (sic) money on a wall," and another wrote, "Hilary because she's not building a wall!" Clinton supporters expressed concern about Trump handling world affairs, making comments like, "I am supporting Hillary because it seems like Trump wants to start another war" and "Hillary Clinton, because if Donald Trump becomes president he may say something wrong that will trigger another country to bomb us."

Gun rights was the only policy of Clinton's that the Trump-supporting students expressed concern about. For example, those students stated, "Clinton is banding guns (sic)" and "Donald trump cause she ain't taken my guns (sic)." Most of the anti-Clinton rationale related to her perceived dishonesty. Several students mentioned her "lying about Benghazi", and others referenced her email scandal. For example, one student wrote, "I really don't like how Hillary Clinton is keeping all of these secrets from us."

Similarly, concerns about Trump's character were prevalent among Clinton supporters. Students wrote comments such as, "I just see Trump as a racist old bully!" and "I don't want Donald Trump to win because he is sexist and racist." A number of students referenced Trump's mocking of a disabled reporter, making comments like, "Trump on one hand has made fun of disabled people and a ton of stuff live on TV." Student sup- 
porters on both sides frequently referenced "the lesser of two evils" with comments like, "Trump because in my opinion he is the less of the 2 evils (sic)" and "at least she's not Donald Trump."

Despite the students' overwhelmingly disdain for the other candidate, they did identify reasons for supporting their preferred candidates. Trump supporters primarily wrote about the wall ("Trump cause we need to build a wall to keep the Mexicans out (sic)"), his business experience (" $[\mathrm{H}] \mathrm{e}$ knows how to handle money since he is a businessman which could be good for our economy"), and protectionism/nationalism ("He is going to make American great again by keeping jobs in the US").

Clinton supporters frequently mentioned her gender as a justification for their support, with comments like, "I feel like she gives young women more confidence" and, "HC just because she supports woman (sic)." They also referenced her experience in politics. For example, one student wrote:

She is the most qualified candidate that we have ever had in the Presidential Debate because she was in the White House as first lady, she was Secretary of State, she knows what the nations wants, she has hosted fund raisers for children and America and she was a senator (sic).

We find it noteworthy that in the nearly 200 comments students provided for why they were supporting or rejecting a particular candidate, none referenced health care.

\section{Pre-Election Political Typologies}

On the PEW Political Typology quiz, a plurality (27\%) of students were classified as Solid Liberals, followed by Next Generation Left (22.8\%) and Faith and Family Left (20.2\%). A majority of those students indicated that they supported Clinton. Less than $13 \%$ of students were classified as conservatives - either Steadfast Conservative (9.6\%) or Business Conservative $(2.6 \%)$, the majority of whom supported Trump. Compared with the more than 10,000 Americans surveyed by PEW in 2014, these 115 8th-grade students were more liberal and less conservative.

\section{Election Unit}

Throughout the election unit, students completed a number of assignments designed for them to examine the candidates' platforms, consider multiple perspectives, and defend their positions. The teachers limited oral in-class debates, and instead directed student discourse predominantly to writing assignments. Each student had a laptop, which the teachers allowed them to use primarily to access the candidates' own websites, as well as CNN Student News, NPR, and politifact.com.

Early in the unit, the teachers struggled to get the students to focus on the issues rather than on the candidates' personalities and past actions, real or exaggerated. Through some well-designed lessons using video, internet, and print media, the teachers were able to guide students in formulating their personal platforms around the candidates' espoused plans for their presidency. In one assignment, students were required to write a letter to their preferred candidate, with the following components: 
- Explain if you are a liberal/conservative/Democrat/Republican/other and what that means

- Discuss three social issues that are meaningful to you and talk about how you know about the candidate's stance on each issue

- Discuss three different social issues that you know are meaningful to the American public by asking three questions about how the candidate is going to deal with these issues.

- Offer three pieces of advice to the candidate in the remaining weeks of the campaign to help the candidate potentially gain favor in the states that are swing states or with the audiences that $\mathrm{s} /$ he still could use some support from

The student letters were surprisingly thoughtful and substantive, and represented a wide range of issues including, but not limited to, minimum wage, taxes, police brutality, LGBTQ rights, terrorism, guns, immigration, and abortion.

\section{Election Day}

The school is located in one of eight (of 83 total) counties in Michigan with a majority vote for Clinton. Consistent with national results for young voters (18-29-year-olds), the students preferred Clinton by a wide majority. In an anonymous school-wide election, Clinton won by 20 points. In a nationwide poll of 150,000 schoolchildren, Clinton received $52 \%$ of the votes to Trump's 35\% (www.scholastic.com/vote).

\begin{tabular}{lcccc}
$\begin{array}{l}\text { Table 1 } \\
\text { Election Results }\end{array}$ & & & \\
\hline Candidate & Site School & County & State & Nation \\
\hline Clinton & $55.60 \%$ & $48.30 \%$ & $47.30 \%$ & $48.20 \%$ \\
Trump & $35.10 \%$ & $44.10 \%$ & $47.60 \%$ & $46.30 \%$ \\
Johnson & $4.80 \%$ & $4.40 \%$ & $3.60 \%$ & $3.20 \%$ \\
Stein & $4.40 \%$ & $1.80 \%$ & $1.10 \%$ & $1 \%$ \\
\hline
\end{tabular}

Among the 115 8th-grade students in this study, Clinton received $56.5 \%$ of the votes to Trump's 30.4\%. Both candidates received more votes than they did in the pre-election, but a much greater number of initially undecided voters committed to Clinton (from $40.9 \%$ to $56.5 \%$ ) than to Trump (from $27 \%$ to $30.4 \%$ ).

Table 2

Students' Pre- and Post-Unit Candidate Preferences

\begin{tabular}{lcc}
\hline Candidate & Pre-Election & Election Day \\
\hline Clinton & $40.90 \%$ & $56.50 \%$ \\
Trump & $27 \%$ & $30.40 \%$ \\
Johnson & $0.90 \%$ & $3.50 \%$ \\
Stein & $0 \%$ & $5.20 \%$ \\
None & $31.30 \%$ & $4.30 \%$ \\
\hline
\end{tabular}




\section{Election-Day Political Typologies}

On the PEW Political Typology quiz taken on Election Day, Solid Liberals were most common (31.6\%), followed by Next Generation Left (18.3\%) and Faith and Family Left (14.0\%). These three top categories on Election Day were consistent with the pre-election results with students much more liberal overall on the pre $(70 \%)$ and post $(63.9 \%)$ surveys than the public overall (42\%). Following the unit, slightly more students were conservative $(15.7 \%)$ than on the pre-survey $(12.2 \%)$, but were still less conservative than the public overall (22\%).

While the number of students scoring in the each of the typologies pre and post is quite similar, a surprising number of students' political typologies changed during the unit. More than half $(54.8 \%)$ of the students' typologies changed on the post-survey. For example, of the 23 students who were categorized as Faith and Family Left on the presurvey, only 7 (30.4\%) were categorized as Faith and Family Left on the post-survey; and, of the 26 students who were categorized as Next Generation Left on the pre-survey, only $10(38.5 \%)$ were categorized as Next Generation Left on the post-survey. The most crystallized were the $22(71 \%)$ Solid Liberals whose typologies did not change.

\section{After the Election}

The day after the election, the teachers reported there was "a palpable atmosphere of shock, disbelief, and anger" throughout the school. To settle their students, they assigned the following four questions to answer individually as seatwork:

1. What are your fears?

2. What are your hopes?

3. What questions do you have?

4. What can you do about it?

Many of the student responses to Question \# 1 closely matched concerns students had expressed about Donald Trump at the start of the unit and throughout the unit, though some issues we had not yet heard from the students. Students expressed general fears, writing things like, "He will make other countries hates us" and "Donald Trump is going to tarnish the reputation of America." Others were more dystopian, saying: "The world is going to blow up" and, "We are going to have World War III."

Students expressed concern about a number of common issues such as building the wall and deportation of immigrants, the repeal of the Affordable Care Act, and "tax breaks for the upper 1\%." A number of students expressed fears related to LGBTQ rights, expressing things like, "LGBT people will have to take conversion therapy to be straight and will end up committing suicide" and "gay marriage will become illegal."

The Trump supporters mostly wrote that they did not have any fears. One student expressed fear that President Trump would not get to do the things he wants to. Conversely, an anti-Trump student wrote, "I am afraid he will actually try to do the things he 
said at his campaign speeches." Finally, one astute student hinted at the power of checks and balances to limit the power of the president, stating, "I'm not really afraid because the senate or congress or whoever will make sure nothing bad happens (sic)".

The majority of the students' hopes were the antitheses of their fears. For example, one student wrote, "I hope [he] doesn't do all that stuff I listed in the fears box", and another student wrote, "that Trump doesn't do half of the stuff he said he'll do." A surprising number of students were hopeful in their responses, writing things like, "I hope that things aren't as bad as I think" and, "[I hope] Donald Trump will come forward and be the mature adult he should be." Likewise, several students expressed how they hoped Trump "will make America great again."

When asked to list questions they had, students again referenced the issues that pervaded the unit. For example, students asked questions like, "Will he really build the wall?" and, "What is going to do about ISIS?" Most, of their questions, however, expressed their incredulity with the outcome of the election. Students asked questions such as, "How did America let this happen?" and "How did Hilary actually lose?" Several students conveyed amazement that "so many women actually voted for him", asking questions like, "How come Hillary was beating Trump for like debates and stuff but then all of a sudden he wins?" Students were curious about how the vote defied polling. For example, one student wrote, "How did Trump get so many electoral votes with less popular votes?" Another student asked, "Was the election rigged?"

The final question produced the most surprising responses, particularly because the students, who up until this point had been quite verbose, did not offer substantive ideas for what they could about the election results. By far, the most common responses were statements like, "nothing", "I really can't do much about it," and, "wait for 4 years." Several students referenced their age when expressing their inability effect change, writing statements like, "I'm 13 what do you want me to do?? Start a gay riot at the White House? I think not" (sic) and, "I don't think I can do anything. I am just a kid."

Out of the 115 students whose responses we analyzed, only a handful offered any ideas for actions they could take. One student said she'd "get others to start an impeachment." A couple of students referenced their ability to vote in four years. For example, one student wrote, "Nothing until the next election bc then I can vote" (sic). Other students wrote, "I can come up with good arguments and do my best to make sure he isn't re-elected in four years" and, "I can encourage some of my friends to vote democratic in the next election."

A number of students said they wanted to escape, with statements like, "move out of America" and "move to Canada." Despite the ubiquitous tone of disdain, a few students were positive and expressed hope. For example, one student wrote, "Try to stay optimistic," and another wrote, "Stay positive. Stay supportive. Stay open to his ideas."

\section{Limitations}

We have identified a number of limitations of this study. First, we are not certain that the 115 students from whom we collected complete data are representative of all 212 8thgrade students. The teachers reported it is typical for $25 \%$ of students to fail to complete 
assigned tasks. Assumedly, these students represent a low-achieving subgroup of the student population, which may have skewed our data. Some of the 97 (46\%) students who failed to complete all tasks were absent for reasons including illness and sports.

Another limitation relates to social pressures that were pervasive throughout the unit, including during our surveys. For example, while taking the PEW political typology survey students could be heard reading questions aloud and asking their neighbors how they answered. Also, students may have publicly supported one candidate or another because their friends did.

Finally, we would like to point out that despite the students' changed typologies, it is not clear why their perspectives changed. Furthermore, we do not know if their typologies will continue to change or when they will crystallize.

\section{Discussion}

"Democracies need actively engaged democrats to persist and to resist internal threats" (Reichert, 2016b). Approximately one-quarter of the US population is under 18 years old, and most of those citizens are and will continue to be susceptible to internal threats, despite their inability to vote. The extent to which the Trump administration represents a threat will not be settled anytime soon; as of this writing, the polarization in the US over Trump's words and actions in undeniable. The US has never had a president with a higher disapproval rating at the end of his first month (PEW Research Center, 2017). A democracy allows its citizens to act on their disapproval. A widely accepted belief about democracy is that it is improved by having an informed, engaged citizenry. Disenfranchised citizens, including minors, should develop the capacity to become informed and active.

Compared with previous cohorts, Millennials participate less in political activities (Flanagan \& Levine, 2010; Gallup, 2016). Because political interest predicts civic participation (Leighley \& Vedlitz, 1999; Stromback \& Shehata, 2010), presidential elections "provide unique 'teachable moments' for educators to leverage students' out-of-school experiences to strengthen their interest in related issues" (Levy et al., 2016).

A key component of political socialization, "political efficacy is a person's ability to understand his government and to feel competent in changing it" (Massialas et al., 1970). By all accounts, the students in this study exhibited one aspect of political efficacy - understanding of issues, but none of the second component - a sense of agency regarding what they can do. Massialas called out schools for their failure to take a leadership role in the political socialization of students. Rather, schools have "maintained an attitude of passivity and compliance". Among his suggestions were for schools to move to an inquiry model with student-generated ideas and a focus on social issues students care about.

Clearly, the students in this student cared about the 2016 Presidential Election. The teachers' reports, student work, and our observations confirm that the students were passionately engaged in the campaign and aftermath. Learning about politics and social issues during early adolescence is vital because as people move from adolescence to adulthood, their political orientations tend to become more rigid (Osborne, Sears, \& 
Valentino, 2011; Reichert, 2016a; Sears \& Valentino, 1997). Precisely when this crystallization of political orientations occurs is not known; however, our study demonstrates that 13- and 14-year-olds' political ideologies are quite malleable. More than half $(55 \%)$ of the students' political typologies changed over the six weeks. Here it is important to differentiate between political attitudes and ideologies, and political party affiliation. Much of the related literature on political socialization has focused on party affiliation, which tends to remain stable (Abrams \& Fiorina, 2015; Harton \& Tweten, 2014). The PEW political typology survey was designed to identify participants" "attitudes and values, not their partisan labels" (Dimock et al., 2014). The PEW typology eschews the typical left-right continuum and instead clusters people who share similar views on "a range of political values including attitudes about size and scope of government, the social safety net, immigration, homosexuality, business, the environment, foreign policy and racial discrimination".

While the students in this study commonly changed their political attitudes and values, only one of the 79 students who declared their preferred candidate at the start of the unit changed his mind over the six weeks. Nearly $99 \%$ of the students who made up their minds about the candidates they supported at the start of the unit continued to support the same candidates. It is important to keep in mind, however, that this Presidential Election was unique in that both candidates had historically high unfavorable ratings (Gallup, 2016). As such, people voted against the other candidate as often as the voted for a candidate. The students' comments bear this out. What's more, the 2016 Presidential Election saw a nontrivial number of voters switch parties (Weigel, 2016).

By all accounts, the students in this study are what Almond and Verba (2015) called the subject type of citizen, those who are intellectually engaged in the political process but passive about their participation. Similarly, the students could be categorized as personally responsible citizens (Westheimer \& Kahne, 2004). Personally responsible citizens obey laws, help in their communities, and take voting seriously. Unlike participatory citizens or justice-oriented citizens, the students in this study represent a conventional notion of citizenship; they possess a sense of duty but lack willingness or ability to engage in the political process (Dalton, 2008). Whereas conventional perspectives on citizenship involve party identification, awareness of issues, and political discussion (Reichert, 2016b), political engagement involves "efforts to affect policy, politics, and institutions of government" (Wicks, Wicks, Morimoto, Maxwell, \& Schulte, 2014).

The students in this study were knowledgeable, ideological, and passionate about the election and candidates, yet beyond noting that they will be able to vote in approximately four years, the student did not mention actions they could take to engage in the political process. The teachers in the study can be commended for igniting students' interest in and focus on the election, which relates to (Sears \& Valentino, 1997) impressionable years hypothesis. However, in order move students' interest to actionable engagement in the political system, the teachers should teach the students about actions they can take, such as writing to their political representatives, attending rallies and town hall meetings, boycotting, and even participating in online communities (Reichert, 2016a; Wicks et al., 2014). When students feel a sense of belonging and connectedness, they are more likely to "act on behalf of a common good" (Flanagan et al., 2010). 


\section{References}

Abrams, S. J., \& Fiorina, M. P. (2015). Party sorting. In Thurber, J., Yoshinaka, A. (Eds.), American gridlock. New York: Cambridge University Press.

Almond, G. A., \& Verba, S. (2015). The civic culture: Political attitudes and democracy in five nations. Princeton, NJ: Princeton University Press.

Campbell, J. L., Quincy, C., Osserman, J., \& Pedersen, O. K. (2013). Coding in-depth semistructured interviews: Problems of unitization and intercoder reliability and agreement. Sociological Methods E Research, 42(3), 294-320.

Cohen, C. J., \& Kahne, J. (2011). Participatory politics. New media and youth political action, youth $\mathcal{E}$ participatory politics. Chicago, IL: MacArthur Foundation.

Conover, P., \& Searing, D. D. (2000). A political socialization perspective. In L. McDonnel, P. Timpane, and R. Benjamin (eds.), Rediscovering the Democratic Purposes of Education. Lawrence, KA: University Press of Kansas.

Conover, P. J. (1991). Political socialization: Where's the politics. Political Science: Looking to the Future, 3, 125-52.

Dalton, R. J. (2008). Citizenship norms and the expansion of political participation. Political Studies, 56(1), 76-98.

Dalton, R. J. (2009). The good citizen: How a younger generation is reshaping American politics. Washington, DC: CQ Press.

Dawson, R., \& Prewitt, K. D. (1977). Political socialization. Toronto: Little, Brown and Company.

Dimock, M., Doherty, C., Kiley, J., \& Krishnamurthy, V. (2014). Beyond red vs. blue: The political typology. Pew Research Center.

Easton, D. (1965). A systems analysis of political life. New York: J. Wiley.

Flanagan, C. (2009). Young people's civic engagement and political development. In A. Furlong (Ed.), Handbook of youth and young adulthood. New perspectives and agendas. London: Routledge.

Flanagan, C., \& Levine, P. (2010). Civic engagement and the transition to adulthood. The Future of Children, 20(1), 159-179.

Flanagan, C., Stoppa, T., Syvertsen, A. K., \& Stout, M. (2010). Schools and social trust. In L. R. Sherrod, C. A. Flanagan \& J. TorneyPurta (Eds.), Handbook of research on civic engagement in youth. New York, NY: Wiley.

Gallup. (2016). Presidential election 2016: Key indicators. Retrieved from http://www.gallup.com/poll/189299/presidential-election-2016 -key-indicators.aspx

Gordon, H. R., \& Taft, J. K. (2011). Rethinking youth political socialization: Teenage activists talk back. Youth $\mathcal{E}$ Society, 43(4), 1499-1527.

Goren, P. (2005). Party identification and core political values. American Journal of Political Science, 49(4), 881-896.

Greenstein, F. I. (1965). Children and politics. New Haven: Yale University Press.

Harton, H. C., \& Tweten, C. (2014). Loyal fans or rational good citizens? Motivated social cognition and political party identification. Psyccritiques, 59(26). doi: 10.1037/ a0036999 
Hess, R. D., \& Torney, J. V. (1967). The development of political attitudes in children. New Brunswick, NJ: Aldine.

Hogg, M. A., \& Terry, D. I. (2000). Social identity and self-categorization processes in organizational contexts. Academy of Management Review, 25(1), 121-140.

Hyman, H. (1959). Political socialization. New York: Free Press.

Jennings, M. K., \& Niemi, R. G. (1968). The transmission of political values from parent to child. American Political Science Review, 62(1), 169-184.

Kahne, J., Crow, D., \& Lee, N.-J. (2013). Different pedagogy, different politics: High school learning opportunities and youth political engagement. Political Psychology, 34(3), 419-441.

Leech, N. L., \& Onwuegbuzie, A. J. (2009). A typology of mixed methods research designs. Quality \& Quantity, 43(2), 265-275.

Leighley, J. E., \& Vedlitz, A. (1999). Race, ethnicity, and political participation: Competing models and contrasting explanations. The Journal of Politics, 61(4), 1092-1114.

Levy, B. L., Journell, W., He, Y., \& Towns, B. (2015). Students blogging about politics: A study of students' political engagement and a teacher's pedagogy during a semester-long political blog assignment. Computers $\mathcal{E}$ Education, 88(1), 64-71.

Levy, B. L., Solomon, B. G., \& Collet-Gildard, L. (2016). Fostering political interest among youth during the 2012 presidential election: Instructional opportunities and challenges in a swing state. Educational Researcher, 45(9), 483-495.

Massialas, B. G., et al. (1970). Structure and process of inquiry into social issues in secondary schools. Ann Arbor: University of Michigan.

McLeod, J., Shah, D., Hess, D., \& Lee, N.-J. (2010). Communication and education: Creating competence for socialization into public life. In L. R. Sherrod, C. A. Flanagan $\mathcal{E} J$. TorneyPurta (Eds.), Handbook of research on civic engagement in youth. New York, NY: Wiley.

Mizelle, N. B., \& Irvin, J. L. (2000). Transition from middle school into high school. Middle School Journal, 31(5), 57-61.

Nelms, C., Allen, M. W., Craig, C. A., \& Riggs, S. (2017). Who is the adolescent environmentalist? Environmental attitudes, identity, media usage and communication orientation. Environmental Communication, 11(4), 537-553.

Neundorf, A., Smets, K., \& García-Albacete, G. M. (2013). Homemade citizens: The development of political interest during adolescence and young adulthood. Acta Politica, 48(1), 92-116.

Niemi, R. G., \& Hepburn, M. A. (1995). The rebirth of political socialization. Perspectives on Political Science, 24(1), 7-16.

Onwuegbuzie, A. J., \& Leech, N. L. (2004). Enhancing the interpretation of significant findings: The role of mixed methods research. The Qualitative Report, 9(4), 770-792.

Ornstein, N. J., Kohut, A., \& McCarthy, L. (1988). The people, the press \& politics: The times mirror study of the American electorate. Reading, MA: Addison Wesley Publishing Company.

Osborne, D., Sears, D. O., \& Valentino, N. A. (2011). The end of the solidly democratic south: The impressionable-years hypothesis. Political Psychology, 32(1), 81-108. 
Owen, D. (2008). Political socialization in the twenty-first century: Recommendations for researchers. In Paper presented at The Future of Civic Education in the 21st Century Conference, James Madison Montpelier, VA.

Owen, D., \& Soule, S. (2015). Political knowledge and dimensions of political engagement. Paper prepared for presentation at the Annual Meeting of the American Political Science Association, San Francisco, CA, September 3-6, 2015.

PEW Research Center. (2017). Early public attitudes about Donald Trump. Retrieved from http://www.people-press.org/2017/02/16/1-early-public -attitudes-about-donald-trump/

Prior, M. (2010). You've either got it or you don't? The stability of political interest over the life cycle. The Journal of Politics, 72(3), 747-766.

Reichert, F. (2016a). Students' perceptions of good citizenship: A person-centred approach. Social Psychology of Education, 19(3), 661-693.

Reichert, F. (2016b). Who is the engaged citizen? correlates of secondary school students' concepts of good citizenship. Educational Research and Evaluation, 22(5-6), 305-332.

Ritchie, R. A., Meca, A., Madrazo, V. L., Schwartz, S. J., Hardy, S. A., Zamboanga, B. L., ... Ham, L. S. (2013). Identity dimensions and related processes in emerging adulthood: Helpful or harmful? Journal of Clinical Psychology, 69(4), 415-432.

Sapiro, V. (2004). Not your parents' political socialization: Introduction for a new generation. Annual Review of Political Science, 7(1), 1-23.

Sears, D. O., \& Valentino, N. A. (1997). Politics matters: Political events as catalysts for preadult socialization. American Political Science Review, 91(1), 45-65.

Snyder, T., \& Musu-Gillette, L. (2015). Free or reduced price lunch: A proxy for poverty. National Center for Educational Statistics Blog. In National Conference of State Legislatures.

Strauss, A., \& Corbin, J. (1998). Basics of qualitative research: Techniques and procedures for developing grounded theory. Thousand Oaks, CA: Sage.

Stromback, J., \& Shehata, A. (2010). Media malaise or a virtuous circle? Exploring the causal relationships between news media exposure, political news attention and political interest. European Journal of Political Research, 49(5), 575-597.

Tajfel, H., Billig, M. G., Bundy, R. P., \& Flament, C. (1971). Social categorization and intergroup behaviour. European Journal of Social Psychology, 1(2), 149-178.

Tingsten, H. (1937). Political behavior: Studies in election statistics. London: P. S. King \& Son.

Turner, J. C., \& Reynolds, K. J. (2011). Self-categorization theory. Handbook of theories in social psychology, 2(1), 399-417.

Uslaner, E. M. (2017). Political trust, corruption, and inequality. In Zmerli S, van der Meer T. (Eds.), Handbook on Political Trust. Cheltenham, UK: Edward Elgar Publishing.

van Deth, J. W., Abendschon, S., \& Vollmar, M. (2011). Children and politics: An empirical reassessment of early political socialization. Political Psychology, 32(1), 147-174.

van Ingen, E., \& van der Meer, T. (2016). Schools or pools of democracy? A longitudinal test of the relation between civic participation and political socialization. Political Behavior, 38(1), 83-103. 
Weigel, D. (2016). How voters who heavily supported Obama switched over to Trump. The Washington Post.

Weissberg, R. (1974). Political learning, political choice and democratic citizenship. Englewood Cliffs, NJ: Prentice-Hall.

Westheimer, J., \& Kahne, J. (2004). What kind of citizen? The politics of educating for democracy. American Educational Research Journal, 41(2), 237-269.

Wicks, R. H., Wicks, J. L., Morimoto, S. A., Maxwell, A., \& Schulte, S. R. (2014). Correlates of political and civic engagement among youth during the 2012 presidential campaign. American Behavioral Scientist, 58(5), 622-644.

Youniss, J., Bales, S., Christmas-Best, V., Diversi, M., Mclaughlin, M., \& Silbereisen, R. (2002). Youth civic engagement in the twenty-first century. Journal of Research on Adolescence, 12(1), 121-148.

Youniss, J., McLellan, J. A., \& Yates, M. (1997). What we know about engendering civic identity. American Behavioral Scientist, 40(5), 620-631. 